RESEARCH ARTICLE

\title{
Studies on the Growth and Yield of Rice under Various Establishment Methods and Water Management Strategies in Tank Irrigated Command Areas
}

\author{
Selvakumar $\mathbf{S}^{1^{*}}$, Sakthivel $\mathbf{S}^{2}$, Akihiko kamoshita ${ }^{3}$, Babu $\mathbf{R}^{4}$, Thiyageshwari $\mathbf{S}^{5}$ and Raviraj $\mathbf{A}^{6}$ \\ ${ }^{1}$ Department of Agronomy, Tamil Nadu Agricultural University, Coimbatore 641003 \\ ${ }^{2}$ Department of Agronomy, AC\&RI, Tamil Nadu Agricultural University, Madurai - 625104 \\ ${ }^{3}$ Asian Natural Environmental Science Center, University of Tokyo - 1138657 , Japan \\ ${ }^{4}$ Department of Crop Management AC \& R I, Tamil Nadu Agricultural University, Kudumiyanmalai 622 104, \\ ${ }^{5}$ Department of Soil Science and Agricultural Chemistry, Tamil Nadu Agricultural University, Coimbatore - 641003 \\ ${ }^{6}$ Water Technology Center, Tamil Nadu Agricultural University, Coimbatore 641003
}

Received : $12^{\text {th }}$ June, 2020

Revised : 06 ${ }^{\text {th }}$ July, 2020

Revised : $28^{\text {th }}$ July, 2020

Accepted : $12^{\text {th }}$ August, 2020

\begin{abstract}
To study the effect of various establishment and water management practices on rice, a field experiment was conducted at Periyar Vaigai Command (PVC) during summer 2019. The experiments comprised of four establishment methods in main plots viz., conventional transplanting $\left(\mathrm{M}_{1}\right)$, machine transplanting under puddled soil $\left(\mathrm{M}_{2}\right)$, machine transplanting under unpuddled soil $\left(\mathrm{M}_{3}\right)$ and sowing with seed drill $\left(\mathrm{M}_{4}\right)$; four irrigation management practices in sub plots viz., farmers' irrigation practice $\left(\mathrm{I}_{1}\right)$, Irrigation after formation of hairline crack $\left(\mathrm{I}_{2}\right)$, irrigation when water level reaches $5 \mathrm{~cm}$ below soil surface $\left(\mathrm{I}_{3}\right)$ and irrigation when water level reaches $10 \mathrm{~cm}$ below soil surface $\left(\mathrm{I}_{4}\right)$. The results of the study revealed that machine transplanting under unpuddled soil recorded 6.5 per cent higher yield compared to conventional manual planting. Among the irrigation management strategies, irrigation after formation of hairline crack recorded 8.1 per cent higher yield compared to farmer's irrigation practice, which was comparable with irrigation when water level reaches $5 \mathrm{~cm}$ below soil surface. Significant interaction was observed with establishment methods and irrigation management practices. This study concluded that machine transplanting under unpuddled soil combined with irrigation when water level reaches $5 \mathrm{~cm}$ below soil surface will be the suitable management technology to be adopted by the rice growing farmers in tank irrigated command areas.
\end{abstract}

Keywords: Establishment methods; Irrigation management; Growth; Yield and Water productivity.

\section{INTRODUCTION}

Rice is the most important staple food, eaten by more than a half of the world's population. In Asia, the term Food security can be well related to Rice security as $90 \%$ of rice is consumed in this region. Worldwide, water for agriculture is getting increasingly scarce and it is estimated that by 2025, 15-20 million ha of irrigated rice fields may suffer from water scarcity (CGIAR, 2016). In India alone drought will cause as much as $40 \%$ yield loss, amounting to 6,500 crores annually. In southern parts of India, mostly rice is grown in command areas under tank irrigation system. Due to delayed onset, early withdrawal and decreased quantity of monsoon rains, releasing of water from dams get delayed and the availability of water in tanks for irrigation also get reduced. The rice crop grown in these command areas suffer terminal stress and the farmers could not achieve higher yield.
Farmers are mostly following manual transplanting under puddled soil condition and puddling alone requires $200 \mathrm{~mm}$ of water, which is $16.12 \%$ of total water requirement. Puddling causes subsurface hardpan at $15-25 \mathrm{~cm}$, it affected the root growth of the rice, which in turn reduced the nutrient availability (Boparai et al., 1992) and it required more energy for field preparations (Kumar and Ladha, 2011). To overcome these problems, machine transplanting in unpuddled soil condition can be an alternate strategy, which alsoensures optimum plant population. Direct sowing under puddled soil is also an effective technology to reduce labour requirement rather than transplanting, because transplanting required about 300 to 350 man hrha-1 (Goel et al., 2008) but the TNAU drum

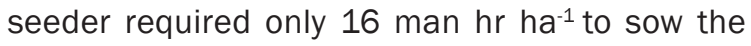
seeds for a hectare of land (Chandrasekhrarao et al., 2013). Moreover, labour scarcity in agricultural 
sector is the emerging problem due to migration of labours from the villages to nearby cities.

Continuous flooding is the common practice followed by the farmers and it consumes large quantity of water. Adopting appropriate irrigation management strategies will save huge quantity of water and helps to bringmore area under cultivation. It also avoid complete crop failures under water deficit situations. Irrigation after the disappearance of ponded water will improve soil aeration and enhance the water use efficiency. Safe alternate wetting and drying can be recommended as a water saving technology that demands irrigation when water depth falls to a threshold depth of below the soil surface by using the field water tube. Several studies revealed that safe AWD significantly reduced the water input without penalty in rice grain yield (Samoy et al., 2008). It is highly essential to evolve the most suited irrigation management strategy under various establishment methods of rice cultivationthat could be recommended to the rice growing farmers in command areas. Hence, a field experiment was conducted to evaluate the growth and yield of rice under various establishment methods and irrigation management strategies to sustain rice production.

\section{MATERIAL AND METHODS}

The field experiment was conducted during summer 2019 at Agricultural College and Research Institute, Tamil Nadu Agricultural University, Madurai, Tamil Nadu, India. The experimental field comes under Periyar Vaigai Command area and is located at $9^{\circ} 54^{\prime} \mathrm{N}$ latitude and $78^{\circ} 54^{\prime} \mathrm{E}$ longitude at an altitude of $147 \mathrm{~m}$ above MSL. Soil texture was sandy clay loam. pH of the soil was 7.2, organic matter of the soil was $0.81 \%$, soil available $\mathrm{N}$ was 242.6 $\mathrm{kg} \mathrm{ha}^{-1}$, available P was $16.9 \mathrm{~kg} \mathrm{ha}^{-1}$ and available $\mathrm{K}$ was $432.7 \mathrm{~kg} \mathrm{ha}^{-1}$. The experiment was laid out in strip plot design with 16 treatment combinations and three replications. The treatments comprised of four different methods of establishment viz., conventional transplanting $\left(\mathrm{M}_{1}\right)$, machine transplanting under puddled soil $\left(\mathrm{M}_{2}\right)$, machine transplanting under unpuddled soil $\left(M_{3}\right)$ and sowing with seed drill $\left(\mathrm{M}_{4}\right)$, respectively in main plots and four irrigation management methods in sub plots viz., farmers' irrigation practice (continuous submergence of 5 $\mathrm{cm}$ throughout the crop period) $\left(I_{1}\right)$, Irrigation after formation of hairline crack (irrigation was given to the depth of $2.5 \mathrm{~cm})\left(\mathrm{I}_{2}\right)$, irrigation when water level reaches $5 \mathrm{~cm}$ below soil surface (each irrigation was given to the depth of $2.5 \mathrm{~cm})\left(\mathrm{I}_{3}\right)$ and irrigation when water level reaches $10 \mathrm{~cm}$ below soil surface (each irrigation was given to the depth of $2.5 \mathrm{~cm})\left(\mathrm{I}_{4}\right)$. The medium duration fine grain rice variety TKM 13 was used for experimentation. All the nutrient and weed management practices were followed as per TNAU recommendation. All the biometric observations like plant height $(\mathrm{cm})$, tillers $\mathrm{m}^{-2}$,drymatter production (DMP) ( $\left.\mathrm{kg} \mathrm{ha}^{-1}\right)$, root length $(\mathrm{cm})$, root dry weight (g plant ${ }^{-1}$ ) and root volume (cc plant ${ }^{-1}$ ) were observed during physiological maturity and yield attributes viz, number of productive tillers $\mathrm{m}^{-2}$, number of grains per panicle, panicle length, panicle weight and yield viz, grain yield, straw yield and harvesting index were recorded during harvest of the crop. These data were analysed statistically by following Gomez and Gomez (1984) method. Wherever the treatment differences were found significant ( $F$ test), critical differences were worked out at five per cent probability level and the values were furnished. Treatment differences that were not significant denoted as "NS".

\section{RESULTS AND DISCUSSION}

\section{Plant height}

Significantly higher plant height was observed with conventional method of transplanting $\left(\mathrm{M}_{1}\right)$ and recorded plant height of $108.0 \mathrm{~cm}$ compared to conventional manual transplanting (Table 1). Hugar et al., (2009) also observed that conventional method of transplanting produced taller plants. Among the irrigation management practices, taller plants were observed with farmers' method of irrigation $\left(I_{1}\right)(109.6 \mathrm{~cm})$ and it was on par with irrigation after formation of hairline crack $\left(\mathrm{I}_{2}\right)$. Continuous flooding increased the meristamatic cell activity and cell elongation that resulted in increased stem growth rate, ultimately promoted the plant height of rice (Chowdhury et al., 2014). The plant height was significantly decreased with increasing moisture stress (Sariam and Anuar, 2010).

\section{Total number of tillers}

Among the establishment methods, machine transplanting under unpuddled soil $\left(\mathrm{M}_{3}\right)$ produced distinctly more number of tillers $\mathrm{m}^{-2}$ (Table 1 ). However, it was on par with machine transplanting under puddled soil $\left(\mathrm{M}_{2}\right)$ (Table 1$)$. Mechanical transplanter could produce optimum depth of planting under unpuddled soil condition and maintained optimum plant population (Kamboj et al., 2013 and Islam et al., 2014), Hossain et al., 2017 stated that buried hill, floating hill or missing hill were not observed with machine transplanting under unpuddled situation, more over the more number of tillers $\mathrm{m}^{-2}$ under machine transplanting might be due to planting of more number of seedlings per hill, which resulted in increased number of tillers $\mathrm{m}^{-2}$ and efficient utilization of growth resources (Haqueet al., 2016). Lesser number of tillers $\mathrm{m}^{-2}$ (298) was observed in sowing with seed drill, it might be due to poor establishment and population maintenance (Table 1). 
Table 1. Effect of establishment methods and irrigation management practices on plant growth parameters of rice

\begin{tabular}{|c|c|c|c|c|c|c|}
\hline Treatment & $\begin{array}{l}\text { Plant height } \\
\text { (cm) }\end{array}$ & Tillers $\mathrm{m}^{-2}$ & $\begin{array}{l}\text { Drymatter production } \\
\qquad\left(\mathrm{kg} \mathrm{ha}^{-1}\right)\end{array}$ & $\begin{array}{l}\text { Root length } \\
\quad(\mathrm{cm})\end{array}$ & $\begin{array}{l}\text { Root dry } \\
\text { weight (g) }\end{array}$ & $\begin{array}{l}\text { Root volume } \\
\text { (cc hill'-1) }\end{array}$ \\
\hline \multicolumn{7}{|l|}{ Main plot } \\
\hline $\mathrm{M}_{1}$ & 108.0 & 362 & 13174 & 27.1 & 9.49 & 53.5 \\
\hline $\mathrm{M}_{2}$ & 101.5 & 410 & 13370 & 28.5 & 10.05 & 54.1 \\
\hline $\mathrm{M}_{3}$ & 102.7 & 419 & 13946 & 31.7 & 10.61 & 59.3 \\
\hline $\mathrm{M}_{4}$ & 94.9 & 298 & 12335 & 25.8 & 8.69 & 51.3 \\
\hline SEd & 2.5 & 8 & 312 & 0.8 & 0.19 & 1.2 \\
\hline $\mathrm{CD}(0.05)$ & 6.1 & 20 & 765 & 1.8 & 0.47 & 3.0 \\
\hline \multicolumn{7}{|l|}{ Sub plot } \\
\hline $\mathrm{I}_{1}$ & 109.6 & 366 & 13497 & 24.6 & 9.94 & 54.7 \\
\hline $\mathrm{I}_{2}$ & 105.6 & 422 & 14233 & 26.5 & 10.21 & 58.8 \\
\hline $\mathrm{I}_{3}$ & 102.0 & 411 & 13961 & 29.8 & 10.09 & 55.0 \\
\hline $\mathrm{I}_{4}$ & 90.1 & 290 & 11134 & 32.3 & 8.62 & 49.7 \\
\hline SEd & 1.9 & 8 & 249 & 0.9 & 0.27 & 2.0 \\
\hline CD (0.05) & 4.6 & 19 & 610 & 2.2 & 0.66 & 4.9 \\
\hline \multicolumn{7}{|l|}{$\mathrm{M} \times \mathrm{I}$} \\
\hline SEd & 5.0 & 13 & 450 & 1.4 & 0.40 & 2.8 \\
\hline CD (0.05) & NS & 29 & 1021.13 & NS & NS & NS \\
\hline \multicolumn{7}{|l|}{$\mathrm{I} \times \mathrm{M}$} \\
\hline SEd & 4.7 & 13 & 409 & 1.5 & 0.44 & 3.2 \\
\hline CD (0.05) & NS & 28 & 912.10 & NS & NS & NS \\
\hline
\end{tabular}

Between the irrigation management practices, irrigation after formation of hairline crack $\left(\mathrm{I}_{2}\right)$ recorded higher number of tillers of $422 \mathrm{~m}^{-2}$, which was comparable with irrigation when water level reaches $5 \mathrm{~cm}$ below soil surface (Table 1). It might be due to better aeration, which enhanced the growth of root and nutrient absorption therefore resulted in more growth and tiller production. The same results were observed by Hameed et al. (2011) and Kunnathadi et al. (2015).

Table 2. Effect of establishment methods and irrigation management practices on yield parameters and yield of rice

\begin{tabular}{|c|c|c|c|c|c|c|}
\hline Treatment & $\begin{array}{l}\text { Productive } \\
\text { tillers } \mathrm{m}^{-2}\end{array}$ & $\begin{array}{c}\text { Filled grains } \\
\text { panicle }^{-1}\end{array}$ & $\begin{array}{c}\text { Fertility } \\
\text { percentage }\end{array}$ & $\begin{array}{l}\text { Grain yield } \\
\left(\mathrm{kg} \mathrm{ha}^{-1}\right)\end{array}$ & $\begin{array}{l}\text { Straw yield } \\
\left(\mathrm{kg} \mathrm{ha}^{-1}\right)\end{array}$ & $\begin{array}{l}\text { Harvesting } \\
\text { index }\end{array}$ \\
\hline \multicolumn{7}{|c|}{ Main plot } \\
\hline $\mathrm{M}_{1}$ & 290 & 224 & 91.7 & 5430 & 6967 & 0.438 \\
\hline $\mathrm{M}_{2}$ & 304 & 229 & 92.3 & 5573 & 7067 & 0.441 \\
\hline $\mathrm{M}_{3}$ & 342 & 249 & 93.0 & 5807 & 7256 & 0.445 \\
\hline $\mathrm{M}_{4}$ & 252 & 205 & 90.8 & 4967 & 6403 & 0.437 \\
\hline SEd & 7 & 5 & 1.4 & 118 & 142 & 0.009 \\
\hline $\mathrm{CD}(0.05)$ & 16 & 12 & NS & 289 & 347 & NS \\
\hline \multicolumn{7}{|l|}{ Sub plot } \\
\hline$I_{1}$ & 309 & 233 & 94.2 & 5404 & 6939 & 0.438 \\
\hline $\mathrm{I}_{2}$ & 328 & 245 & 92.4 & 5878 & 7424 & 0.442 \\
\hline $\mathrm{I}_{3}$ & 314 & 235 & 91.5 & 5658 & 7269 & 0.438 \\
\hline $\mathrm{I}_{4}$ & 238 & 194 & 89.8 & 4837 & 6060 & 0.444 \\
\hline SEd & 7 & 5 & 2.2 & 118 & 164 & 0.004 \\
\hline CD (0.05) & 17 & 11 & NS & 290 & 400 & NS \\
\hline \multicolumn{7}{|l|}{$\mathrm{M} \times \mathrm{I}$} \\
\hline SEd & 10 & 6 & 4.0 & 174 & 205 & 0.013 \\
\hline $\mathrm{CD}(0.05)$ & 23 & 15 & NS & 393 & 464 & NS \\
\hline \multicolumn{7}{|l|}{$I \times M$} \\
\hline SEd & 10 & 6 & 4.3 & 174 & 221 & 0.010 \\
\hline $\mathrm{CD}(0.05)$ & 23 & 14 & NS & 394 & 505 & NS \\
\hline
\end{tabular}

Various establishment and irrigation management practices showed significant interaction with each other. Machine transplanting under unpuddled soil condition combined with irrigation after formation of hairline crack $\left(\mathrm{M}_{3} \mathrm{I}_{2}\right)$ recorded higher tiller number, which was comparable with Machine transplanting

$107|7-9| 232$ 
under unpuddled soil condition combined with irrigation when water level reaches $5 \mathrm{~cm}$ below soil surface $\left(\mathrm{M}_{3} \mathrm{I}_{3}\right)$.

\section{Drymatter production}

Machine transplanting under unpuddled soil $\left(\mathrm{M}_{3}\right)$ produced 5.5 percent higher drymatter production than conventional transplanting (Table 1). This might be due to proper crop establishment because machine transplanting under unpuddled situation that recorded no floating or buried hill and missing hill (Hossain et al., 2017), this in turn increased the number of tillers, number of leaves, leaf area index.
Moreover, puddling created sub surface hardpan at $15-25 \mathrm{~cm}$ below soil surface (Kukal and Aggarwal, 2003) that hindered the root growth and ultimately affected the nutrient uptake. However, previously mentioned problem was avoided when transplanting was done under unpuddled soil and it promoted higher root growth and nutrient uptake by plant. In the presence of adequate nutrient availability and larger photosynthesizing surface, the drymatter accumulation preceded at a rapid rate leading to its greater accumulation. The results was in line with the findings of Haque et al.(2016).

Table 3. Effect of establishment methods and irrigation management practices on total water used and water productivity in rice

\begin{tabular}{|c|c|c|c|c|c|c|c|c|c|c|c|}
\hline \multirow[t]{2}{*}{ Treatment } & \multicolumn{5}{|c|}{ Consumptive Use (mm) } & \multicolumn{6}{|c|}{ Water productivity $\left(\mathrm{kg} \mathrm{m}^{-3}\right)$} \\
\hline & $\mathbf{M}_{1}$ & $\mathbf{M}_{2}$ & $\mathbf{M}_{3}$ & $\mathbf{M}_{4}$ & Mean & & $\mathbf{M}_{1}$ & $\mathbf{M}_{2}$ & $\mathbf{M}_{3}$ & $\mathbf{M}_{4}$ & Mean \\
\hline $\mathrm{I}_{1}$ & 1253 & 1253 & 1292 & 1311 & 1277 & $I_{1}$ & 0.43 & 0.43 & 0.46 & 0.38 & 0.42 \\
\hline $\mathrm{I}_{2}$ & 1083 & 1083 & 939 & 1099 & 1051 & $I_{2}$ & 0.54 & 0.56 & 0.65 & 0.50 & 0.56 \\
\hline$I_{3}$ & 839 & 839 & 764 & 844 & 822 & $I_{3}$ & 0.68 & 0.68 & 0.77 & 0.63 & 0.69 \\
\hline $\mathrm{I}_{4}$ & 764 & 764 & 714 & 749 & 748 & $\mathrm{I}_{4}$ & 0.63 & 0.68 & 0.74 & 0.54 & 0.65 \\
\hline Mean & 985 & 985 & 927 & 1001 & & & 0.57 & 0.59 & 0.66 & 0.51 & \\
\hline
\end{tabular}

Within the irrigation management practices, higher drymatter production of $14233 \mathrm{~kg} \mathrm{ha}^{-1}$ was recorded with irrigation after formation of hairline crack $\left(\mathrm{I}_{2}\right)$. It was comparable with irrigation when water level reaches $5 \mathrm{~cm}$ below soil surface $\left(I_{3}\right)$ during summer season (Table 1). The increase in DMP of rice with those treatments might be due to production of loose soil with increased aeration, which also facilitated more access to water and transport of nutrients such as nitrate (Gurovich and Oyarce, 2015). This might have helped better plant establishment with higher tiller production, improved leaf area and thick erect leaves.

Machine transplanting under unpuddled soil condition combined with irrigation after formation of hairline crack recorded higher drymatter production (15109 kg ha-1), which was comparable with machine transplanting under unpuddled soil and irrigation when water level reaches $5 \mathrm{~cm}$ below soil surface. It was mainly due to improved growth parameters (Hossain et al., 2017).

\section{Root studies}

Different method of establishment and water management practices influenced the root length; root volume and root dry weight. Machine transplanting under unpuddled soil $\left(\mathrm{M}_{4}\right)$ and irrigation when water level drops $10 \mathrm{~cm}$ below soil surface $\left(\mathrm{I}_{4}\right)$ registered the longer root length of 31.7 and $32.3 \mathrm{~cm}$, respectively (Table 1). Non-availability of surface moisture increased the root length to extract moisture from the deeper layer.
Unpuddled machine transplanting $\left(\mathrm{M}_{3}\right)$ improved the root volume and root dry weight (Table 1) was due to better root activity compared to conventional puddled transplanting. Because under puddled condition, soil structure was destroyed, subsurface impervious hardpan was developed and lower depth of puddled soil had high bulk density, which in turn affected root growth in puddled transplanting (Garg et al., 2000), whereas under unpuddled soil, structure was maintained that enhanced the root growth and nutrient availability. The similar results were observed by Huang et al., (2011).

Irrigation after formation of hairline crack $\left(\mathrm{I}_{2}\right)$ favoured the root growth in terms of root volume and dry weight. It was on par with irrigation when water level reaches $5 \mathrm{~cm}$ below soil surface $\left(I_{3}\right)$ (Table 1 ). Because in both the treatments the soil was kept with optimum moisture and aerated condition, this helped the plant root to get oxygen and water easily. This might favoured the better root growth in the recent study and Thakur et al., (2010), reported similar findings.

\section{Yield attributes}

More number of productive tillers $\left(342 \mathrm{~m}^{-}\right.$ $\left.{ }^{2}\right)$ and grains per panicle (249) were observed with machine transplanting under unpuddled soil $\left(\mathrm{M}_{3}\right)$ (Table 2). This might be due to higher number of productive tillers, increased nutrient availability in soil, improved root activity, increased nutrient uptake, maintenance of optimum plant population per unit area, uniform depth of planting 
by machine transplanting under unpuddled soil (Haque et al., 2016). Uniform spacing increased the production of productive tillers and grains per panicle (Haque et al., 2016). Singh et al., (2019) also confirmed that yield attributes like number of productive tillers $\mathrm{m}^{-2}$ and number of filled grains per panicle were higher under transplanting of rice under unpuddled condition compared to transplanting under puddled soil condition.

Among the irrigation management practices, irrigation after formation of hairline crack $\left(\mathrm{I}_{2}\right)$ recorded improved yield attributing characters of rice viz., number of productive tillers $\mathrm{m}^{-2}$, number of grains panicle ${ }^{-1}$, which was comparable with irrigation when water level reaches $5 \mathrm{~cm}$ below soil surface $\left(I_{3}\right)$ (Table 2). Yield attributes closely linked with drymatterproduction during panicle formation (Pham et al., 2004). Better aeration in the soil, profused root system and increased uptake of all other nutrients contributed for favourable growth attributes, which in turn produced higher yield attributes. This is in line with conclusions of Veeraputhiran et al., (2010). Higher tiller production under irrigation after formation of hairline crack favoured production of higher number of productive tillers, due to the enhanced nutrient uptake and development of more floral and fruiting bodies i.e., this treatment produced panicle with high productive components, which helped the sink to receive the photosynthates from assimilating surface and store effectively under favourable soil plant water status (Satyanarayana et al., 2007).

Rice establishing methods and irrigation management practices showed significant interaction during summer season 2019. Machine transplanting under unpuddled soil with irrigation after formation of hairline crack $\left(\mathrm{M}_{3} \mathrm{I}_{2}\right)$ registered more number of filled grains panicle ${ }^{-1}$ (Table 2). It also saved water to the tune of $27.7 \%$ over conventional transplanting with farmers' irrigation practice $\left(\mathrm{M}_{1} \mathrm{I}_{1}\right)$ (Table 3 ). This falls in line with the findings of Satyanarayana (2005) and Haque et al.,(2016).

\section{Grain and straw yield}

Significantly increased grain and straw yield were observed with machine transplanting under unpuddled soil $\left(\mathrm{M}_{3}\right)$ compared to machine transplanting under puddled soil $\left(\mathrm{M}_{2}\right)$, conventional method of transplanting $\left(\mathrm{M}_{1}\right)$ and sowing with seed drill $\left(\mathrm{M}_{4}\right)$ (Table 2). Higher yield of machine transplanting under unpuddled soil $\left(\mathrm{M}_{1}\right)$ might be due to improved root mass, increased nutrient availability, improved nutrient uptake, proper transplanting depth, higher hill density, uniform transplanting efficiency, lesser percentage of damaged hill and minimum percentage missing hill (Singh et al., 2019, Hossain et al., 2017 and Haque, 2016).
Improved grain and straw yield was observed with irrigation after formation of hairline crack $\left(\mathrm{I}_{2}\right)$. This was on par with irrigation when water level reaches $5 \mathrm{~cm}$ below soil surface $\left(\mathrm{I}_{3}\right)$ (Table $2)$. Thismight be due toincreased number of productive tillers $\mathrm{m}^{-2}$, number of grain panicle${ }^{1}$ with high fertility percentage. Rotational irrigation (safe alternate wetting anddrying) improved soil aeration andimproved root growth and development, enhanced availability of nutrient throughout the crop growth which enriched yield attributes, thereby it increased rice yield. Ceesay et al., (2006) reported that the cycles of repeated wetting and drying improved rice growth and yield through increased nutrient availability.

Significant interaction was observed between establishment methods and irrigation management practices on rice grain and straw yield. Machine transplanting under unpuddled soil combined with irrigation after formation of hairline crack $\left(\mathrm{M}_{3} \mathrm{I}_{2}\right)$ was observed with $13 \%$ increase in grain yield compared to conventional transplanting with farmers' irrigation practice of $5 \mathrm{~cm}$ of continuous flooding $\left(\mathrm{M}_{1} \mathrm{I}_{1}\right)$ during summer 2019 (Table 2). It was comparable with machine transplanting under unpuddled soil combined with irrigation when water level reaches $5 \mathrm{~cm}$ below soil surface $\left(\mathrm{M}_{3} \mathrm{I}_{3}\right)$. This might be due to improved root development, larger canopy, less intra plant competition, improved remobilization of assimilates to grain and higher nutrient availability.

\section{Total water consumed and water productivity}

Among the various establishment methods, machine transplanting under unpuddled soil $\left(\mathrm{M}_{3}\right)$ consumed minimum water $(927 \mathrm{~mm})$ and produced higher water productivity $\left(0.66 \mathrm{~kg} \mathrm{~m}^{-3}\right)$ as compared to other methods of establishment. Farmers' method of irrigation $\left(\mathrm{I}_{1}\right)(5 \mathrm{~cm}$ of continuous submergence throughout the crop growing season) consumed more water (1277 $\mathrm{mm}$ ) and produced lesser water productivity. Water productivity was maximum with irrigation when water level reaches $5 \mathrm{~cm}$ below soil surface $\left(\mathrm{I}_{3}\right)$.

\section{CONCLUSION}

From the experimental result, it could be concluded that machine transplanting under unpuddled soil condition improved plant growth parameters viz., plant height, tillers $\mathrm{m}^{-2}$, drymatter production, root length, root dry weight and root volume. Among the irrigation management practices, irrigation after formation of hairline crack registered increased growth parameter, which was comparable with irrigation whenwater level reaches $5 \mathrm{~cm}$ below soil surface. Yield parameters viz., productive tillers, filled grains panicle ${ }^{-1}$ and grain yield, strawyield also higher withmachine transplanting under unpuddled soil condition and irrigation after formation of 
hairline crack, which was comparable with irrigation whenwater level reaches $5 \mathrm{~cm}$ below soil surface. Higher water productivity was recorded withmachine transplanting under unpuddledsoil condition combined with irrigation whenwater level reaches 5 $\mathrm{cm}$ below soil surface. Hence, machine transplanting under unpuddled soil condition and scheduling of irrigation when water level reaches $5 \mathrm{~cm}$ below soil surfacecan be recommended to the rice growing farmers in tank irrigated command areasto sustain rice production.

\section{FUNDING AND ACKNOWLEDGMENT}

The authors acknowledge the financial support provided by University of Tokyo, through TNAUUTkoyo tank rice project.

\section{Ethics statement}

No specific permits were required for the described field studies because no human or animal subjects were involved in this research.

\section{Originality and plagiarism}

Authors should ensure that they have written and submit only entirely original works, and if they have used the work and/or words of others, that this has been appropriately cited. Plagiarism in all its forms constitutes unethical publishing behavior and is unacceptable.

\section{Consent for publication}

All the authors agreed to publish the content.

\section{Competing interests}

There were no conflict of interest in the publication of this content

\section{AUTHOR CONTRIBUTIONS}

Research grant-AK; Idea-SS; ConceptualizationSS; SS,AK'; Experiments-SS,SS,AK ; GuidanceSS,AK,BR,TS,RA; Writing-original draft-SS;Writingreviewing \&editing-SS,TS, RA

\section{REFERENCES}

Boparai, B.S., Singh, Y., and Sharma, B. D. 1992. Effect of green manuring with Sesbaniaaculeata on physical properties of soil and on growth of wheat in rice-wheat and maize-wheat cropping systems in a semiarid region of India. Arid Land Res. Manage. 6(2): 135-143.https://doi. org/10.1080/15324989209381306

Ceesay, M., Reid, W.S., Fernandes, E.C. and Uphoff,N.T.,2006. The effects of repeated soil wetting and drying on lowland rice yield with System of Rice Intensification (SRI) methods. Int. J. Agric. Sustain. 4(1): 5-14.

CGIAR. (2016). The global staple. http://ricepedia.org/ rice-asfood/the-global-staple-rice-consumers

Chandrasekhrarao, C., Jitindranath, S., \& Murthy, T. G.
K., 2013. Resource optimisation in rice through direct seeding by drum seeder. Int. J. Agric. Food Sci. Technol. 4(3): 239-246.

Chowdhury, M.R., Kumar. V., Sattar, A. and Brahmachari,K.,2014. Studies on the water use efficiency and nutrient uptake by rice under system of intensification. The Bioscan. 9(1): 85-88.

Garg, I. K., Mittal, V. K., and Sharma, V. K. 2000. Effect of ground contact pressure and soil settlement period on paddy transplanter sinkage. J. Agric. Eng. 37(1): 65-70.

Goel, A.K., Behera, D. and Swain, S. 2008. Effect of sedimentation period on performance of rice transplanter. Agric. Eng. Int.: The CIGR e-journal. 10: 1-13.

Gomez, K.A and Gomez.A.A. 1984. Statistical procedures for agricultural research. (2 ${ }^{\text {nd }}$ Ed.), Wiley India Pvt Ltd., India.

Gurovich, L., and Oyarce, P. (2015). New approaches to agricultural land drainage: a review. Irri. Drainage Sys. Eng. 4(135): 2.

Hameed, K., Abbas, A.,Kadhim, J.M. and Jaber, F.A. 2011. Irrigation water reduction using System of Rice Intensification compared with conventional cultivation methods in Iraq. Paddy and Water Environ. 9(1): 121-127.

Haque, M. E., Bell, R. W., Islam, M. A., and Rahman, M. A. 2016. Minimum tillage unpuddled transplanting: An alternative crop establishment strategy for rice in conservation agriculture cropping systems. Field Crops Res. 185: 31-39.https:// doi.org/10.1016/j.fcr.2015.10.018

Hossain, M.M., Ashik-E-Rabbani, M., Elahi, H.M.T., Sarkar, S., Saha, C.K., Alam, M.M., Kalita, P.K. and Hansen, A.C. 2017. Options for Rice Transplanting in Puddled and Un-puddled Soil. In 2017 ASABE Annual International Meeting. American Society of Agricultural and Biological Engineers.

Huang, M., Zou, Y., Feng, Y., Cheng, Z., Mo, Y., Ibrahim, M., Xia, B. and Jiang, P. 2011. No-tillage and direct seeding for super hybrid rice production in rice-oilseed rape cropping system. European J. of Agron. 34(4): 278-286.https://doi.org/10.1016/j. eja.2011.02.005

Hugar, A.Y., Chandrappa. H., Jayadeva.H.M., Sathish.A. and Mallikarjun.G.B. 2009. Influnce of different establishment methods on yield and economics of rice. Agric. Sci. Digest. 29(3): 205-209.

Islam, A. K. M. S., Hossain, M. M., and Saleque, M. A. 2014. Effect of unpuddled transplanting on the growth and yield of dry season rice (Oryza sativa L.) in High Barind Tract. The Agriculturists, 12(2): 91-97.

Kamboj, B. R., Yadav, D. B., Yadav, A. K., Goel, N. K., Gill, G., Malik, R. K., \& Chauhan, B. S. (2013). Mechanized transplanting of rice (Oryza sativa L.) in nonpuddled and no-till conditions in the rice-wheat cropping system in Haryana, India. American J. Plant Sci. 4: 2409-2413.

Kukal, S. S., \& Aggarwal, G.C. (2003). Puddling depth and intensity effects in rice-wheat system on a 
sandy loam soil: I. Development of subsurface compaction. Soil and Tillage Res., 72(1): 1-8.

Kumar. V and Ladha. J.K. 2011.Direct seeding of rice; recentdevelopment and future research needs. $A d v$. Agron. 111: 297-413. https://doi.org/10.1016/ B978-0-12-387689-8.00001-1

Kunnathadi, M., Abraham.C.T., George Thomas. C. and Girija.T. 2015. Comparative evaluation of SRI with conventional system in the irrigated rice tracts of Kerala. J. Tropical Agric., 53(1): 8-16.

Pham, Q.D., Tanaka. D., Abe. A., Sagawa. S. and Kuroda. E. 2004. Analysis of the number of spikelets per panicle on the main stems, primary and secondary tillers of different rice genotypes grown under the conventional and nitrogen-free basal dressing accompanied with sparse planting density practices.Plant Production Sci.7(4): 456-462.

Samoy, K.C., Cantre.M.A.C., Corpuz.A.A., De Dios.J.L., Sibayan. E.B. and Cruz.R.T. 2008. Controlled irrigation in leaf color chart-based and growth stage-base nitrogen management. In: Proc. $38^{\text {th }}$ Annual Scientific Conference of the Crop Science Society of the Philippines, 12-16 May 2008, Iloilo City, Philippines, p. 34.

Sariam, O. and Anuar.A.R. 2010. Effects of irrigation regime on irrigated rice. J. Trop. Agric. Food Sci. 38(1): $1-9$.
Satyanarayana, A. 2005. System of rice intensificationan innovative method to produce more with less water and inputs. In: $4^{\text {th }}$ IWMI-Tata Annual Partners' Meet, IRMA, Anand, India. February 24-26.

Satyanarayana, A., Thiyagarajan.T.M. and Uphoff. N. 2007. Opportunities for water saving with higher yield from the system of rice intensification. Irrig. Sci. 25(2): 99-115.

Singh, S., Singh, A.K., Sohane, R.K., Singh, R.N., Nityanad, N., Kumar, R.R., Kumar, P. and Kumari, S. 2019. Effect of Chemical Weed Management on Growth and Yield in Puddled and Unpuddled Transplanted Rice (Oryza sativa L.). J. of Agri Search, 6(Special): 8-13.

Thakur, A.K., Rath. S., Roychowdhury. S. and Uphoff.N. 2010. Comparative Performance of Rice with System of Rice Intensification (SRI) and Conventional Management using Different Plant Spacings. J. Agron. Crop Sci. 196: 146-159.

Veeraputhiran, R., Balasubramanian. R., Pandian. B.J., Kalidasan. G., Chelladurai. M. and Ganesaraja.V. 2010. Productivity, water use efficiency and economics of system of rice intensification in farmers field of Southern Tamil Nadu. Int. J. Forestry Crop Improvement. 1: 139-142. 